15 Bailar JC, Ederer F. Significance factors for the ratio of a Poisson-variable to its expectation. Biometrics 1964;20: 639-43.

16 Beaumont JJ, Breslow NE. Power consideration in epidemiological studies of vinyl-chloride workers. $\mathrm{Am} \mathrm{J}$ Epidemiol 1981;14:725-43.

17 Saracci R, Simonato L, Acheson ED, et al. Mortality and incidence of cancer of workers in the man made vitreous fibres producing industry: an international investigation at 13 European plants. Br J Ind Med 1984;41:425-36.

18 Kalbfleisch JD, Prentice RL. The statistical analysis of failure time data. New York: Wiley, 1980.

19 Kiesselbach N, Lange H-J, Korallus U. Möglichkeiten und Qualitätssicherung epidemiologischer Untersuchungen im betriebsärztlichen Bereich. In: Verhandlungen der Deutschen 을 Gesellschaft für Arbeitsmedizin. 25. Jahrestagung in Dortmund. Gentner Verlag, 1985;627-33.

20 Claude J, Eilber U, Chow KW, Frentzel-Beyme R. Validity of cause of death statements from relatives. Int Arch Occup Environ Health 1984;54:335-43.

21 Hogstedt C, Aringer L, Gustavsson A. Epidemiologic support $\overline{\bar{\sigma}}$ for ethylene oxide as a cancer-causing agent. $J A M A \overrightarrow{\mathbb{D}}$ $1986 ; 255: 1575-8$

22 Gardner MJ, Coggon D, Pannett B, Harris EC. A follow up study of workers exposed to ethylene oxide. $\mathrm{Br} J$ Ind Med 1989;46:860-5.

Accepted 5 May 1989

\section{A mediaeval accident at work}

During the mediaeval period two great industries, agriculture and building, occupied the mass of the working population in this country either directly or in the trades allied to them. The great delight in researching this period is in studying the illustrations depicting men and women at work in manuscripts, painting, sculpture, or in carving. The burden of ill health resulting from work must have been considerable and allusions are sometimes made to it, particularly in reference to mining, but detailed accounts of occupational diseases seem very thin on the ground. There is little doubt that those who were engaged in building must have suffered a good deal from accidental injuries and we know that a number of cathedrals, for example, collapsed with loss of life. Only when someone of importance was injured, however, do we find a written account; thus we know that Williams of Sens who supervised the rebuilding of Canterbury Cathedral after the fire of 1174 fell from some scaffolding and sustained serious injury but survived. I have been able to find only a few illustrations of accidents at work, one of which is shown here. It comes from a double을 sided painting by Lorenzo di Niccolo Serini (1342-1411) depicting episodes in the life of St Vita. The original is in $\overrightarrow{\overline{\vec{\sigma}}}$ the town museum of San Gimignano in Italy. A workman is 3 shown putting a roof on a small building and as he is working the scaffolding on which he is standing breaks but his fall to the ground is prevented by the miraculous intervention of the saint; judging from the state of the scaffolding, this was the only safety measure available to 3 him. Details of other illustrations of mediaeval hazards ato work would be much appreciated.

HA WALDRON Editor

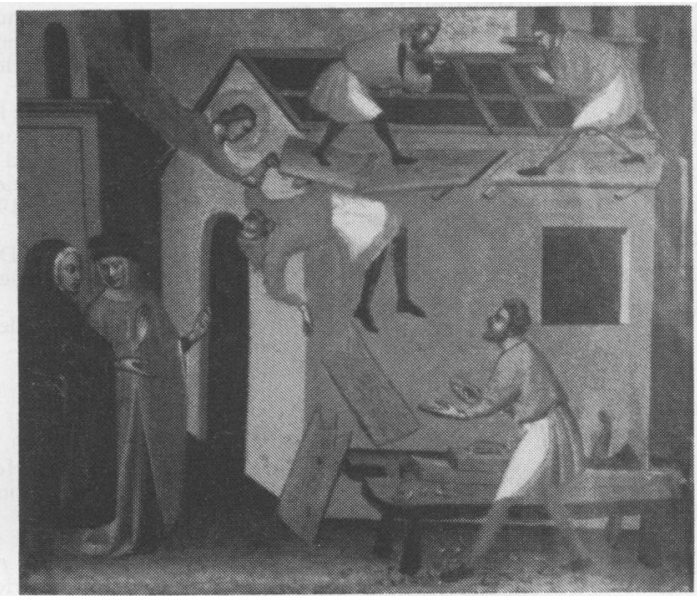

